\title{
IDEOLOGI KADER HIMPUNAN MAHASISWA ISLAM (HMI) DALAM PEMBANGUNAN KEPEMIMPINAN KEPEMUDAAN DI KOTA MEDAN
}

\author{
Suwandi Simangungsong, Ridwan Hanafiah, dan Agus Purwoko \\ Perencanaan Pembangunan Wilayah dan Pedesaan \\ Sekolah PascaSarjana Universitas Sumatera Utara \\ suwandisimangunsong@gmail.com
}

\begin{abstract}
Abstrak
Tujuan penelitian ini adalah Untuk mengetahui signifikansi hubungan antara Kader Himpunan Mahasiswa Islam (HMI) terhadap Pembangunan Kepemudaan di Kota Medan. Untuk mengetahui signifikansi hubungan antara Ideologi Kader Himpunan Mahasiswa Islam (HMI) dalam Pembangunan Kepemimpinan Kepemudaan di Kota Medan. Juga untuk mengetahui signifikansi hubungan antara Penerapan Ideologi HMI Terhadap Kader Himpunan Mahasiswa Islam (HMI) dalam Mengatasi Masalah Pembangunan Kepemimpinan Kepemudaan di Kota Medan.. Metode yang digunakan dalam penelitian ini adalah metode analisis deskripif dengan pendekatan kuantitatif. Teknik pengumpulan data dilakukan dengan menggunakan kuisioner yang disebarkan pada Himpunan Mahasiswa Islam (HMI) Cabang Medan dengan jumlah sample sebanyak 98 responden. Dari hasil penelitian menunjukkan bahwa terdapat hubungan yang signifikan antara Kader Himpunan Mahasiswa Islam (HMI) terhadap Pembangunan Kepemudaan di Kota Medan. Ideologi Kader Himpunan Mahasiswa Islam (HMI) juga memiliki Hubungan yang signifikan Dalam Pembangunan Kepemimpinan Kepemudaan di Kota Medan. Serta Ada hubungan yang signifikan antara Penerapan Ideologi HMI Terhadap Kader Himpunan Mahasiswa Islam (HMI) Dalam Mengatasi Masalah Pembangunan Kepemimpinan Kepemudaan di Kota Medan.
\end{abstract}

Kata Kunci: Himpunan Mahasiswa Islam (HMI), Pembangunan, Kepemimpinan Kepemudaan

\section{PENDAHULUAN}

Medan sebagai kota yang berkembang dan terdiri dari masyarakat yang berbagai macam ragam suku, etnis, sosial, kebudayaan, agama, pendidikan, ekonomi, merupakan wujud kemajemukan sebagai miniatur Indonesia. Ini akan membentuk kualitas sumber daya pemudanya yang berbeda pula. Himpunan Mahasiswa Islam (HMI) yang berazas dan berpahaman bahwa Islam menjadi dasar berpijakan dalam berorganisasi tentunya yang dituntut adalah menciptakan sumber daya manusia yang memiliki kemampuan akademisi yang baik, aktif di masyarakat dan berkarakter menjaga nilai nilai yang islami berdasarkan AlQur'an dan Hadist. Ini melekat pada diri kader HMI sebagai wujud implementasi 
dari Nilai Dasar Perjuangan HMI (NDP HMI) sebagai ideologi organisasi. Diharapkan mampu menghasilkan kualitas sumber daya Pemuda Kota Medan yang di cita-citakan.

Tujuan penelitian ini adalah Untuk mengetahui signifikansi hubungan antara Kader Himpunan Mahasiswa Islam (HMI) terhadap Pembangunan Kepemudaan di Kota Medan. Untuk mengetahui signifikansi hubungan antara Ideologi Kader Himpunan Mahasiswa Islam (HMI) dalam Pembangunan Kepemimpinan Kepemudaan di Kota Medan. Juga untuk mengetahui signifikansi hubungan antara Penerapan Ideologi HMI Terhadap Kader Himpunan Mahasiswa Islam (HMI) dalam Mengatasi Masalah Pembangunan Kepemimpinan Kepemudaan di Kota Medan.

\section{METODE}

Metode yang digunakan dalam penelitian ini adalah metode analisis deskripif dengan pendekatan kuantitatif. Teknik pengumpulan data dilakukan dengan menggunakan kuisioner yang disebarkan pada Himpunan Mahasiswa Islam (HMI) Cabang Medan dengan jumlah sample sebanyak 98 responden. Dan dianalisis dengan menggunakan program SPSS versi 17.0.

\section{HASIL PENELITIAN}

\section{Uji Validitas Kuesioner}

Validitas adalah suatu ukuran yang membuktikan bahwa apa yang diamati peneliti sesuai dengan apa yang sesungguhnya terjadi didalam dunia kenyataan, dan apakah penjelasan yang diberikan memang sesuai dengan yang sebenarnya terjadi. Cara mengujinya adalah dengan membuat korelasi skore pada item yang diuji dengan skore total. Dengan menggunakan program SPSS maka dilakukan analisis Pearson Correlation, didapat hasil sebagai berikut.

Tabel 1. Uji Validitas

\begin{tabular}{lrr}
\multicolumn{3}{c}{ Item-Total Statistics } \\
\hline & $\begin{array}{r}\text { Corrected } \\
\text { Item-Total } \\
\text { Correlation }\end{array}$ & $\begin{array}{r}\text { Cronbach's } \\
\text { Alpha if Item } \\
\text { Deleted }\end{array}$ \\
\hline P1 & .337 & .904 \\
P2 & .279 & .905 \\
P3 & .408 & .903 \\
P4 & .339 & .904 \\
P5 & .260 & .906
\end{tabular}

Suwandi Simangunsong, Ridwan Hanafiah, Agus Purwoko|

Ideologi Kader Himpunan Mahasiswa Islam (HMI) dalam Pembangunan Kepemimpinan 


\begin{tabular}{lll} 
P6 & .367 & .904 \\
P7 & .356 & .904 \\
P8 & .382 & .904 \\
P9 & .365 & .904 \\
P10 & .497 & .902 \\
P11 & .445 & .903 \\
P12 & .460 & .903 \\
P13 & .518 & .902 \\
P14 & .460 & .903 \\
P15 & .496 & .902 \\
P16 & .497 & .902 \\
P17 & .467 & .902 \\
P18 & .482 & .902 \\
P19 & .535 & .901 \\
P20 & .539 & .901 \\
P21 & .535 & .901 \\
P22 & .563 & .901 \\
P23 & .536 & .901 \\
P24 & .514 & .902 \\
P25 & .524 & .901 \\
P26 & .551 & .901 \\
P27 & .522 & .901 \\
P28 & .457 & .903 \\
P29 & .448 & .903 \\
P30 & .390 & .903 \\
P31 & .392 & .903 \\
P32 & .379 & .904 \\
P33 & .362 & .904 \\
P34 & .380 & .904 \\
P35 & .387 & .904 \\
\hline & &
\end{tabular}

Kolom Corrected Item Total Correlation pada tabel 1. di atas merupakan korelasi antara skor item dengan skor total item yang akan digunakan untuk menguji validitas instrumen. Dalam hal ini $r_{\text {tabel }}$ ditetapkan sebesar 0,1966 dan diperoleh dari setiap pertanyaan bahwa $r_{\text {hitung }}$ bernilai positif dan $r_{\text {hitung }}>r_{\text {tabel }}$, maka pertanyaan tersebut dapat dikatakan valid.

\section{Uji Reabilitas}

Pengujian reliabilitas dilakukan untuk mengetahui konsistensi atau keteraturan hasil pengukuran suatu instrumen dan hasil pengujian tersebut merupakan ukuran yang benar dari sesuatu yang diukur. Reliabilitas berhubungan dengan konsistensi jawaban kuesioner. Dalam penelitian ini reliabilitas diukur dengan menggunakan metode Alpha Cronbach dengan menggunakan program SPSS 17.0. Nilai alpha yang diperoleh akan dibandingkan dengan $\mathrm{r}_{\text {tabel. }}$. Apabila nilai alpha lebih besar daripada $r_{\text {tabel}}$, maka instrumen tersebut dapat disebut reliabel. Diperoleh hasilnya sebagai berikut: 
Tabel 2. Uji Reabilitas

\section{Reliability Statistics}

\begin{tabular}{|r|r|r|}
\hline Cronbach's Alpha & Cronbach's Alpha Based on Standardized Items & N of Items \\
\hline 801 & .801 & 35 \\
\hline
\end{tabular}

Dari tabel diatas, diperoleh nilai cronbach's alpha 0.801 (temasuk memiliki tingkat reabilitas sangat tinggi), dengan demikian data reliebel dan kuisioner dapat dipercaya dan dapat digunakan untuk penelitian.

\section{Uji Asumsi Klasik}

\section{Uji Normalitas}

Uji normalitas data bertujuan untuk mengetahui apakah dalam model regresi variabel pengganggu atau residual memiliki distribusi normal.Dengan melihat tampilan grafik normal plot pada Gambar 1. dapat disimpulkan bahwa data menyebar di sekitar garis diagonal dan mengikuti arah garis diagonalnya. Hal ini menunjukkan data residual berdistribusi normal.
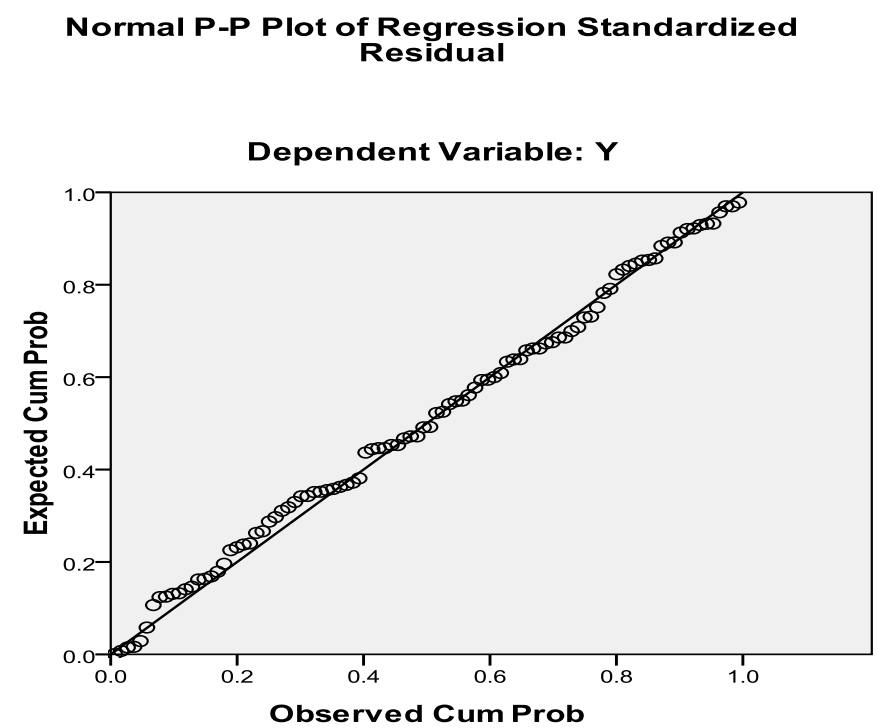

Gambar 1. Hasil uji normalitas 


\section{Uji Multikolinearitas}

Uji Multikolinearitas digunakan untuk mengetahui adanya hubungan antara beberapa atau semua variabel yang menjelaskan dalam model regresi. Jika dalam model terdapat multikolinearitas maka model tersebut memiliki kesalahan standar yang besar sehingga koefisien tidak dapat ditaksir dengan ketepatan yang tinggi. Hasil pengujian multikolinieritas dapat dilihat pada Tabel 1 sebagai berikut :

Tabel 3. Uji Multikolinearitas

\begin{tabular}{|c|c|c|c|c|c|c|c|c|}
\hline \multicolumn{9}{|c|}{ Coefficients $^{\mathrm{a}}$} \\
\hline & & \multicolumn{2}{|c|}{$\begin{array}{l}\text { Unstandardized } \\
\text { Coefficients }\end{array}$} & $\begin{array}{l}\text { Standardized } \\
\text { Coefficients }\end{array}$ & \multirow[b]{2}{*}{$\mathrm{t}$} & \multirow[b]{2}{*}{ Sig. } & \multicolumn{2}{|c|}{$\begin{array}{l}\text { Collinearity } \\
\text { Statistics }\end{array}$} \\
\hline \multicolumn{2}{|c|}{ Model } & $B$ & $\begin{array}{l}\text { Std. } \\
\text { Error }\end{array}$ & Beta & & & Tolerance & VIF \\
\hline \multirow[t]{4}{*}{1} & (Constant) & 12.880 & 3.047 & & 4.227 & .000 & & \\
\hline & $\mathrm{X} 1$ & .231 & .087 & .254 & 2.659 & .009 & .655 & 1.528 \\
\hline & $\mathrm{X} 2$ & .116 & .082 & .157 & 1.411 & .162 & .483 & 2.072 \\
\hline & X3 & .235 & .075 & .357 & 3.120 & .002 & .456 & 2.195 \\
\hline
\end{tabular}

a. Dependent Variable: $Y$

Berdasarkan pada hasil pengolahan data, menunjukkan semua variabel independenmemiliki nilai tolerance lebih besar dari 0,10 dan memiliki nilai Variance Inflation Factor (VIF) lebih kecil dari 10,00 ini berarti dapat disimpulkan bahwa variabel independen tidak terjadi multikolinieritas.

\section{Uji Autokorelasi}

Uji Autokorelasi adalah untuk mengetahui adanya korelasi antara variabel gangguan sehingga penaksir tidak lagi efisien baik dalam model sampel kecil maupun dalam sampel besar. Salah satu cara untuk menguji autokorelasi adalah dengan percobaan d (Durbin-Watson). Hasilnya diperoleh sebagai berikut: 
Tabel 4. Uji Autokoelasi

Model Summary ${ }^{\mathrm{D}}$

\begin{tabular}{|c|c|c|c|c|c|c|c|c|c|c|}
\hline \multirow[b]{3}{*}{ Model } & \multirow[b]{3}{*}{$\mathrm{R}$} & \multirow[b]{2}{*}{$\mathrm{R}$} & \multirow[b]{2}{*}{ Adjusted } & \multicolumn{6}{|c|}{ Change Statistics } & \multirow[b]{2}{*}{ Durbin- } \\
\hline & & & & of the & R Square & $\mathrm{F}$ & & & Sig. $\mathrm{F}$ & \\
\hline & & Square & R Square & Estimate & Change & Change & df1 & df2 & Change & Watson \\
\hline 1 & .662 & .439 & .421 & 1.803 & .439 & 24.474 & & 9 & .000 & 1.916 \\
\hline
\end{tabular}

a. Predictors: (Constant), X3, X1, X2

b. Dependent Variable: $Y$

Dari tabel di atas nilai Durbin-Watson adalah sebesar 1,916, dan nilai du sebesar 1,734. Dengan ketentuan $\mathrm{du}<\mathrm{d}<4$-du, maka dapat kita lihat 1,734< $1,916<2,265$. Artinya bahwa data tersebut tidak terjadi autokorelasi.

\section{d. Uji Heterokedastisitas}

Uji heteroskedastisitas bertujuan untuk menguji apakah model regresi terjadi ketidaksamaan varians dari residual satu pengamatan ke pengamatan yang lain. Untuk mendeteksi ada tidaknya heteroskedastisitas dapat dilakukan dengan melihat grafik scatterplots.

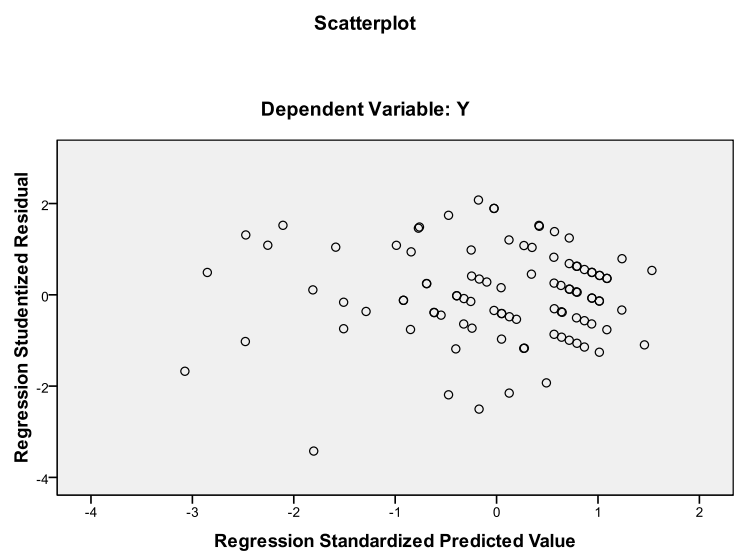

Gambar 2. Hasil uji heterokedastisitas

Dari grafik scatterplot pada gambar 2. menunjukkan bahwa titik-titik menyebar secara acak serta tersebar baik diatas maupun dibawah angka 0 pada 
sumbu Y dan tidak membentuk pola tertentu yang teratur, hal ini dapat disimpulkan bahwa tidak terjadi heteroskedastisitas pada model regresi.

\section{Uji Chi Kuadrat}

Uji ini dapat juga disebut uji keselarasan (goodness of fit test), karena untuk menguji apakah sebuah sampel selaras dengan salah satu distribusi teoritis (seperti distribusi normal, uniform, binomial dan lainnya). Uji Chi-kuadrat dapat juga dilakukan untuk mencari hubungan antara 2 variabel penetapan hipotesis awal dan hipotesis alternatif Sudjana (2005). Pengambilan keputusan dan interprestasi:

Jika Sig di atas 0,05 maka Ho diterima

Jika Sig di bawah 0,05 maka Ho ditolak

Uji Chi Kuadrat Kader Himpunan Mahasiswa Islam (HMI) dalam Pembangunan Kepemudaan di Kota Medan

Tabel 5. Uji Chi Kuadrat Kader Himpunan Mahasiswa Islam (HMI) terhadap Pembangunan Kepemudaan di Kota Medan

\begin{tabular}{lcrr}
\multicolumn{4}{c}{ Chi-Square Tests } \\
& \multicolumn{1}{c}{ Value } & df & $\begin{array}{c}\text { Asymp. Sig. (2- } \\
\text { sided) }\end{array}$ \\
\hline Pearson Chi-Square & $169.551^{\mathrm{a}}$ & 110 & .000 \\
Likelihood Ratio & 116.665 & 110 & .314 \\
Linear-by-Linear Association & 27.825 & 1 & .000 \\
N of Valid Cases & 98 & & \\
\hline
\end{tabular}

Hasil analisis statistik menunjukkan nilai signifikansi $=0,000 \leq 0,05$ berarti disimpulkan ada hubungan yang signifikan antara Kader Himpunan Mahasiswa Islam (HMI) terhadap Pembangunan Kepemudaan di Kota Medan. Selain dengan nilai signifikansi, ada tidaknya hubungan antara Kader Himpunan Mahasiswa Islam (HMI) terhadap Pembangunan Kepemudaan di Kota Medan dapat dilihat dari perbandingan nilai Chi-Square hitung dengan Chi-Square tabel. 
Dimana diperoleh nilai Chi-Square hitung sebesar 169,551 dan lebih besar dari nilai Chi-Square tabel sebesar 135,480 .

\section{Uji Chi Kuadrat Ideologi Kader Himpunan Mahasiswa Islam (HMI) terhadap Pembangunan Kepemimpinan Kepemudaan di Kota Medan}

Tabel 6. Uji Chi Kuadrat Ideologi Kader Himpunan Mahasiswa Islam (HMI) terhadap Pembangunan Kepemimpinan Kepemudaan di Kota Medan

\begin{tabular}{lccr}
\multicolumn{4}{c}{ Chi-Square Tests } \\
& Value & Df & $\begin{array}{c}\text { Asymp. Sig. (2- } \\
\text { sided) }\end{array}$ \\
\hline Pearson Chi-Square & $277.113^{\mathrm{a}}$ & 143 & .000 \\
Likelihood Ratio & 143.611 & 143 & .470 \\
Linear-by-Linear Association & 28.318 & 1 & .000 \\
N of Valid Cases & 98 & & \\
\hline $\begin{array}{l}\text { a. 168 cells (100.0\%) have expected count less than 5. The minimum } \\
\text { expected count is .01. }\end{array}$
\end{tabular}

Hasil analisis statistik menunjukkan nilai signifikansi $=0,000 \leq 0,05$ berarti disimpulkan ada hubungan yang signifikan antara Ideologi Kader Himpunan Mahasiswa Islam (HMI) terhadap Pembangunan Kepemudaan di Kota Medan. Selain dengan nilai signifikansi, ada tidaknya hubungan antara Ideologi Kader Himpunan Mahasiswa Islam (HMI) terhadap Pembangunan Kepemudaan di Kota Medan dapat dilihat dari perbandingan nilai Chi-Square hitung dengan Chi-Square tabel. Dimana diperoleh nilai Chi-Square hitung sebesar 277,113 dan lebih besar dari nilai Chi-Square tabel sebesar 171,907.

Uji Chi Kuadrat Penerapan Ideologi HMI Terhadap Kader Himpunan Mahasiswa Islam (HMI) dalam Mengatasi Masalah Pembangunan Kepemimpinan Kepemudaan di Kota Medan 
Tabel 7. Uji Chi Kuadrat Penerapan Ideologi HMI Terhadap Kader Himpunan Mahasiswa Islam (HMI) dalam Mengatasi Masalah Pembangunan Kepemimpinan Kepemudaan di Kota Medan

\begin{tabular}{lcrr}
\multicolumn{4}{c}{ Chi-Square Tests } \\
& \multicolumn{1}{c}{ Value } & df & $\begin{array}{c}\text { Asymp. Sig. (2- } \\
\text { sided) }\end{array}$ \\
\hline Pearson Chi-Square & $229.936^{\text {a }}$ & 143 & .000 \\
Likelihood Ratio & 131.503 & 143 & .745 \\
Linear-by-Linear Association & 36.033 & 1 & .000 \\
N of Valid Cases & 98 & & \\
\hline
\end{tabular}

a. 168 cells $(100.0 \%)$ have expected count less than 5 . The minimum expected count is .01 .

Hasil analisis statistik menunjukkan nilai signifikansi $=0,000 \leq 0,05$ berarti disimpulkan ada hubungan yang signifikan antara Ideologi Kader Himpunan Mahasiswa Islam (HMI) dalam memberikan solusi Pembangunan Kepemudaan di Kota Medan. Selain dengan nilai signifikansi, ada tidaknya hubungan antara Ideologi Kader Himpunan Mahasiswa Islam (HMI) dalam memberikan solusi Pembangunan Kepemudaan di Kota Medan dapat dilihat dari perbandingan nilai Chi-Square hitung dengan Chi-Square tabel. Dimana diperoleh nilai Chi-Square hitung sebesar 229,936 dan lebih besar dari nilai Chi-Square tabel sebesar 143,246.

\section{Uji Korelasi}

Analisis korelasi sederhana (Bivariate Correlation) digunakan untuk mengetahui keeratan hubungan antara dua variabel dan untuk mengetahui arah hubungan yang terjadi. Koefisien korelasi sederhana menunjukkan seberapa besar hubungan yang terjadi antara dua variabel. Nilai korelasi (r) berkisar antara 1 sampai -1 , nilai semakin mendekati 1 atau -1 berarti hubungan antara dua variabel semakin kuat, sebaliknya nilai mendekati 0 berarti hubungan antara dua variabel semakin lemah. Nilai positif menunjukkan hubungan searah (X naik maka Y naik) dan nilai negatif menunjukkan hubungan terbalik (X naik maka Y turun). 


\section{Hubungan Kader Himpunan Mahasiswa Islam (HMI) dalam Pembangunan}

\section{Kepemudaan di Kota Medan}

Tabel 8. Uji Korelasi Kader Himpunan Mahasiswa Islam (HMI) dalam Pembangunan Kepemudaan di Kota Medan

\begin{tabular}{|c|c|c|c|}
\hline \multicolumn{4}{|c|}{ Correlations } \\
\hline & & $\mathrm{X} 1$ & $\mathrm{Y}$ \\
\hline \multirow[t]{3}{*}{$\mathrm{X} 1$} & Pearson Correlation & 1 & $.536^{\prime \prime}$ \\
\hline & Sig. (2-tailed) & & .000 \\
\hline & $\mathrm{N}$ & 98 & 98 \\
\hline \multirow[t]{3}{*}{$\mathrm{Y}$} & Pearson Correlation & $.536^{\wedge}$ & 1 \\
\hline & Sig. (2-tailed) & .000 & \\
\hline & $\mathrm{N}$ & 98 & 98 \\
\hline
\end{tabular}

Hasil analisis statistik menunjukkan nilai Pearson Correlation untuk Variabel Kader Himpunan Mahasiswa Islam (HMI) (X1) terhadap variabel Pembangunan Kepemimpinan Kepemudaan (Y) adalah sebesar 0,536. Hasil ini lebih besar dibandingkan dengan $r$ tabel sebesar 0,1986. Ini menunukkan bahwa variabel Kader Himpunan Mahasiswa Islam (HMI) memiliki hubungan terhadap variabel Kepemimpinan Kepemudaan (Y) dengan nilai koefisien korelasi sedang tetapi positif. Artinya, jika nilai variabel Kader Himpunan Mahasiswa Islam (HMI) naik maka nilai variabel terikat Kepemimpinan Kepemudaan juga akan mengalami kenaikan.

Pengujian koefisien korelasi sederhana adalah sebagai berikut:

Ho: Tidak tedapat hubungan yang signifikan antara Kader Himpunan Mahasiswa Islam (HMI) terhadap Pembangunan Kepemimpinan Kepemudaan, jika nilai t hitung < nilai t tabel dan nilai signifikansi > 0,05 .

Ha: Tedapat hubungan yang signifikan antara Kader Himpunan Mahasiswa Islam (HMI) terhadap Pembangunan Kepemimpinan Kepemudaan, jika nilai t hitung > nilai $\mathrm{t}$ tabel dan nilai signifikansi $<0,05$. 
Tabel 9. Uji t Kader Himpunan Mahasiswa Islam (HMI) dalam Pembangunan Kepemudaan di Kota Medan

Coefficients $^{\mathrm{a}}$

\begin{tabular}{lrrrrrr}
\hline & & \multicolumn{2}{c}{$\begin{array}{c}\text { Unstandardized } \\
\text { Coefficients }\end{array}$} & $\begin{array}{c}\text { Standardized } \\
\text { Coefficients }\end{array}$ & & \\
\cline { 2 - 5 } Model & B & $\begin{array}{c}\text { Std. } \\
\text { Error }\end{array}$ & Beta & t & Sig. \\
\hline $1 \quad$ (Constant) & 16.677 & 3.221 & & 5.177 & .000 \\
X1 & .488 & .079 & .536 & 6.214 & .000 \\
\hline
\end{tabular}

Hasil analisis statistik menunjukkan nilai t hitung sebesar 6,214. Jika dibandingkan dengan $\mathrm{t}$ tabel sebesar 1,66, maka nilai $\mathrm{t}$ hitung $>$ nilai $\mathrm{t}$ tabel $(6,214>1,66)$ serta nilai signifikansi $0,000<0,05$. Artinya, Tedapat hubungan yang signifikan antara Kader Himpunan Mahasiswa Islam (HMI) terhadap Pembangunan Kepemimpinan Kepemudaan.

Tabel 10. Uji Korelasi Ideologi Kader Himpunan Mahasiswa Islam (HMI) Dalam Pembangunan Kepemimpinan Kepemudaan di Kota Medan

\begin{tabular}{|c|c|c|c|}
\hline \multicolumn{4}{|c|}{ Correlations } \\
\hline & & $\mathrm{X} 2$ & $\mathrm{Y}$ \\
\hline \multirow[t]{3}{*}{$\mathrm{x} 2$} & Pearson Correlation & 1 & .540 \\
\hline & Sig. (2-tailed) & & .000 \\
\hline & $\mathrm{N}$ & 98 & 98 \\
\hline \multirow[t]{3}{*}{$\mathrm{Y}$} & Pearson Correlation & $.540^{\wedge}$ & 1 \\
\hline & Sig. (2-tailed) & .000 & \\
\hline & $\mathrm{N}$ & 98 & 98 \\
\hline
\end{tabular}

Hasil analisis statistik menunjukkan nilai Pearson Correlation untuk Variabel Ideologi Kader Himpunan Mahasiswa Islam (HMI) (X2) terhadap variabel Pembangunan Kepemimpinan Kepemudaan (Y) adalah sebesar 0,54. Hasil ini lebih besar dibandingkan dengan $r$ tabel sebesar 0,1986. Ini menunjukkan bahwa variabel Ideologi Kader Himpunan Mahasiswa Islam (HMI) 
memiliki hubungan terhadap variabel Kepemimpinan Kepemudaan (Y) dengan nilai koefisien korelasi sedang tetapi positif. Artinya, jika nilai variabel Ideologi Kader Himpunan Mahasiswa Islam (HMI) naik maka nilai variabel terikat Kepemimpinan Kepemudaan juga akan mengalami kenaikan.

Pengujian koefisien korelasi sederhana adalah sebagai berikut:

Ho : Tidak tedapat hubungan yang signifikan antara Ideologi Kader Himpunan Mahasiswa Islam (HMI) terhadap Pembangunan Kepemimpinan Kepemudaan, jika nilai t hitung < nilai t tabel dan nilai signifikansi > 0,05 .

Ha: Tedapat hubungan yang signifikan antara Ideologi Kader Himpunan Mahasiswa Islam (HMI) terhadap Pembangunan Kepemimpinan Kepemudaan, jika nilai t hitung > nilai t tabel dan nilai signifikansi < 0,05 .

Tabel 11. Uji t Ideologi Kader Himpunan Mahasiswa Islam (HMI) dalam Pembangunan Kepemimpinan Kepemudaan di Kota Medan

Coefficients $^{a}$

\begin{tabular}{|c|c|c|c|c|c|c|}
\hline \multirow{2}{*}{\multicolumn{2}{|c|}{ Model }} & \multicolumn{2}{|c|}{$\begin{array}{l}\text { Unstandardized } \\
\text { Coefficients }\end{array}$} & \multirow{2}{*}{$\begin{array}{c}\begin{array}{c}\text { Standardized } \\
\text { Coefficients }\end{array} \\
\text { Beta }\end{array}$} & \multirow[b]{2}{*}{$\mathrm{t}$} & \multirow[b]{2}{*}{ Sig. } \\
\hline & & $B$ & $\begin{array}{l}\text { Std. } \\
\text { Error }\end{array}$ & & & \\
\hline \multirow[t]{2}{*}{1} & (Constant) & 20.348 & 2.599 & & 7.828 & .000 \\
\hline & $X 2$ & .398 & .063 & .540 & 6.291 & .000 \\
\hline
\end{tabular}

Dari Hasil analisis statistik di atas dapat dilihat bahwa nilai t hitung sebesar 6,291. Jika dibandingkan dengan t tabel sebesar 1,66, maka nilai t hitung $>$ nilai t tabel $(6,291>1,66)$ serta nilai signifikansi $0,000<0,05$. Artinya, Tedapat hubungan yang signifikan antara Ideologi Kader Himpunan Mahasiswa Islam (HMI) terhadap Pembangunan Kepemimpinan Kepemudaan. 
Hubungan Penerapan Ideologi HMI Terhadap Kader Himpunan Mahasiswa Islam (HMI) dalam Mengatasi Masalah Pembangunan Kepemimpinan Kepemudaan di Kota Medan

Tabel 12. Uji Korelasi Penerapan Ideologi HMI Terhadap Kader Himpunan Mahasiswa Islam (HMI) dalam Mengatasi Masalah Pembangunan Kepemimpinan Kepemudaan di Kota Medan

\begin{tabular}{|c|c|c|c|}
\hline \multicolumn{4}{|c|}{ Correlations } \\
\hline & & X3 & $\mathrm{Y}$ \\
\hline \multirow[t]{3}{*}{$\mathrm{X} 3$} & Pearson Correlation & 1 & $.609^{\prime \prime}$ \\
\hline & Sig. (2-tailed) & & .000 \\
\hline & $\mathrm{N}$ & 98 & 98 \\
\hline \multirow[t]{3}{*}{$\mathrm{Y}$} & Pearson Correlation & $.609^{n}$ & 1 \\
\hline & Sig. (2-tailed) & .000 & \\
\hline & $\mathrm{N}$ & 98 & 98 \\
\hline
\end{tabular}

Hasil analisis statistik menunjukkan nilai Pearson Correlation untuk Variabel Penerapan Ideologi HMI Terhadap Kader Himpunan Mahasiswa Islam (HMI) Dalam Mengatasi Masalah Pembangunan (X3) terhadap variabel Kepemimpinan Kepemudaan (Y) adalah sebesar 0,609. Hasil ini lebih besar dibandingkan dengan $r$ tabel sebesar 0,1986. Ini menunjukkan bahwa variabel Penerapan Ideologi HMI Terhadap Kader Himpunan Mahasiswa Islam (HMI) Dalam Mengatasi Masalah Pembangunan memiliki hubungan terhadap variabel Kepemimpinan Kepemudaan (Y) dengan nilai koefisien korelasi yang kuat dan positif Artinya jika nila variabel Penerapan Ideologi HMI Terhadap Kader Himpunan Mahasiswa Islam (HMI) Dalam Mengatasi Masalah Pembangunan unan naik maka nilai variabel Kepemimpinan Kepemudaan juga akan mengalami kenaikan.

Pengujian koefisien korelasi sederhana adalah sebagai berikut: 
Ho : Tidak tedapat hubungan yang signifikan antara Penerapan Ideologi HMI Terhadap Kader Himpunan Mahasiswa Islam (HMI) Dalam Mengatasi Masalah Pembangunan Kepemimpinan Kepemudaan, jika nilai t hitung < nilai t tabel dan nilai signifikansi $>0,05$.

Ha: Tedapat hubungan yang signifikan antara Penerapan Ideologi HMI Terhadap Kader Himpunan Mahasiswa Islam (HMI) Dalam Mengatasi Masalah Pembangunan Kepemimpinan Kepemudaan, jika nilai t hitung > nilai $\mathrm{t}$ tabel dan nilai signifikansi $<0,05$.

Tabel 13. Uji t Penerapan Ideologi HMI Terhadap Kader Himpunan Mahasiswa Islam (HMI) dalam Mengatasi Masalah Pembangunan Kepemimpinan Kepemudaan di Kota Medan

\section{Coefficients $^{\mathrm{a}}$}

\begin{tabular}{|c|c|c|c|c|c|c|}
\hline \multirow{2}{*}{\multicolumn{2}{|c|}{ Model }} & \multicolumn{2}{|c|}{$\begin{array}{l}\text { Unstandardized } \\
\text { Coefficients }\end{array}$} & \multirow{2}{*}{$\begin{array}{c}\text { Standardized } \\
\text { Coefficients } \\
\text { Beta }\end{array}$} & \multirow{3}{*}{$\frac{t}{9.350}$} & \multirow{3}{*}{$\begin{array}{r}\text { Sig. } \\
.000\end{array}$} \\
\hline & & \multirow{2}{*}{$\begin{array}{c}\text { B } \\
20.335\end{array}$} & \multirow{2}{*}{$\begin{array}{l}\begin{array}{c}\text { Std. } \\
\text { Error }\end{array} \\
2.175\end{array}$} & & & \\
\hline 1 & (Constant) & & & & & \\
\hline & X3 & .400 & .053 & .609 & 7.533 & .000 \\
\hline
\end{tabular}

Dari Hasil analisis statistik di atas dapat dilihat bahwa nilai t hitung sebesar 7,533. Jika dibandingkan dengan t tabel sebesar 1,66, maka nilai t hitung $>$ nilai $\mathrm{t}$ tabel $(7,533>1,66)$ serta nilai signifikansi $0,000<0,05$. Artinya, Tedapat hubungan yang signifikan antara Penerapan Ideologi HMI Terhadap Kader Himpunan Mahasiswa Islam (HMI) Dalam Mengatasi Masalah Pembangunan Kepemimpinan Kepemudaan.

\section{PEMBAHASAN}

Kader Himpunan Mahasiswa Islam (HMI) memiliki hubungan dengan Pembangunan Kepemimpinan Kepemudaan di Kota Medan. Masing-masing variabel menunjukkan hubungan yang positif dan searah serta signifikan terhadap Kepemimpinan Kepemudaan di Kota Medan. Hal ini dapat dilihat dari nilai korelasi yang bernilai positif dan nilai signifikan yang dibawah 0,05. 
Sebagaimana diketahui pada bab sebelumnya bahwa HMI memiliki 5 kualitas insan cita sebagai modal sosial pembangunan manusia, Sebagai organisasi pengkaderan, HMI memiliki pedoman-pedoman khusus dalam mempersiapkan kadernya guna menghadapi tantangan zaman. Setiap kader dituntut untuk bisa memiliki kualitas insan cita, sesuai apa yang tertera di dalam tujuan HMI. Manusia yang di cita-citakan HMI tentunya bukan hanya wacana yang ada dalam konstitusi dan pedoman perkaderan semata, namun terwujud dalam bentuk aksi.

Sebagai pengabdi Bangsa, Negara dan Agama, kader HMI di gamabarkan sebagai pemimpin yang dibutuhkan oleh umat yang mampu mengatasi masalahmasalah yang dialami umat. Seiring berjalannya waktu, HMI banyak melahirkan pemimpin-peminpin yang dibutuhkan umat, seperti di bidang politik dan pemerintahan diantaranya, Bactiar Chamsyah (Mantan Menteri Sosoal RI Ke25) Irgan Chairul Mahfidz (Anggota DPR RI Periode 2009-2014 dan Tahun 20142019), tetapi Kader-kader HMI juga banyak berada di bidang pendidikan diantaranya, Prof. Dr. H.M. Yusuf Hanafiah ( Mantan Rektor USU), Prof. Dr. Hj. Djanius Djamin, SH., MS (Mantan Rektor UNIMED dan juga anggota DPRD Medan Tahun 1968 Selama Dua Periode), Almarhum Prof. Dr. Nur Ahmad Fadhil Lubis, MA (Mantan Rektor dan Pemrakarsa IAIN SU bertranformasi menjadi UIN SU Medan) Prof. Dr. Usman Pelly (Ketua Yayasan UISU). Dan masih banyak lagi alumni-alumni HMI yang berkarir bidang ekonomi, kewirausahaan, hukum, sosial budaya dan agama. Ini membuktikan bahwa HMI dengan ideologinya mampu menciptakan kader-kader yang dibutuhkan umat disegala bidang kehidupan dengan kompetensi 5 kualitas kualitas insan cita dalam pembangunan daerah. Tidak hanya di Pemerintah Pusat tetapi juga didaerah seperti Kota Medan.

\section{KESIMPULAN}

Dari hasil pengujian datayanh telah dilakukan, maka dapat ditarik kesimpulan sebagai berikut : 
1. Ada hubungan yang signifikan antara Kader Himpunan Mahasiswa Islam (HMI) terhadap Pembangunan Kepemudaan di Kota Medan.

2. Ada hubungan yang signifikan antara hubungan Ideologi Kader Himpunan Mahasiswa Islam (HMI) Dalam Pembangunan Kepemimpinan Kepemudaan di Kota Medan.

Ada hubunganyang signifikan antara Penerapan Ideologi HMI Terhadap Kader Himpunan Mahasiswa Islam (HMI) Dalam Mengatasi Masalah Pembangunan Kepemimpinan Kepemudaan di Kota Medan.

\section{SARAN}

Berdasarkan kesimpulan yang diperoleh dari hasil penelitian, maka peneliti memberikan saran - saran sebagai berikut :

1. Bagi Himpunan Mahasiswa Islam (HMI) Kota Medan untuk terus meningkatkan kualitas sumber daya manusia untuk meningkatkan kualitas pemuda khususnya dibidang kepemimpinan, seperti memberikan pelatihanpelatihan kepemimpinan. Untuk mengulang kembali fase kebangkitan HMI 1966-1968.

2. Bagi Pemerintah Kota Medan, harus meningkatkan program-program pemberdayaan pemuda tidak hanya dibidang olahraga tetapi dibidang organisasi kepemudaan agar tercipta pemimpin-pemimpin baru penerus generasi bangsa. Seperti memberdayakan kembali organisasi kepemudaan di setiap kelurahan, organisasi kemahasiswaan ditiap kampus dan lain sebagainya.

3. Bagi peneliti lainnya, penelitian ini mungkin masih banyak terdapat kekurangan sehingga penulis menyarankan untuk menyempurnakan penelitian ini pada masa-masa yang akan datang secara berkesinambungan.

\section{DAFTAR PUSTAKA}

Ali, F, dan Effendy, B. 1986. Merambah Jalan Baru Islam, Rekonstruksi Pemikiran Islam Indonesia Masa Orde Baru, Bandung: Mizan. 
Arifin, S, dan Toborani. 1994. Islam Pluralisme Budaya dan Politi, Sipress.

Barry, M.D. Al dan Lya, S.Y. 2003. Kamus Induk Istilah lmiah ; Seri Intelektual, Surabaya, Target Press, h. 33, 349.

Bratakusumah, D.S Dan Riyadi. 2005. Perencanaan Pembangunan Daerah. Jakarta: PT. Gramedia Pustaka Utama

Budiman, A. 2000. Teori Pembangunan Dunia Ketiga. Jakarta. Gramedia Putaka Utama

Danim, S. 1996. Transformasi Sumber Daya Manusia. Jakarta: Bumi Aksara.

Depdikbud, 1984. Kamus Besar Bahasa Indonesia. Jakarta : Balai Pustaka.

Esposito, J.L. 1994. terj. Alwiyah Abdurrahman dan Missi, Ancaman Islam Mitos Atau Realitas?, Bandung: Mizan.

Fattah, N. 2000. Landasan Manajement pendidikan, Bandung: PT. Remaja Rosada karya, cet Ke-3, h.54-56.

Friedman. 1998. Keperawatan Keluarga. Jakarta: EGD.

Gibson, I. and Donnelly. 1995. Oragnizations, 8 Ed. Alih bahasa oleh: $\quad$ Nunur Ardiani, 1996, Organisasi, Edisi 8 Jilid I. Jakarta: Binarupa Aksara.

Gottschalk, L. 1985. Mengerti Sejarah, terj. Nugroho Notosusanto, Jakarta: UI Press.

Ghozali, I. 2011. “Aplikasi Analisis Multivariate Dengan Program SPSS”. Semarang: Badan Penerbit Universitas Diponegoro.Hartono. 2004 Statistik:Untuk Penelitian Yogyakarta: Pustaka Pelajar Offset.

Hartono. 2004 Statistik:Untuk Penelitian Yogyakarta: Pustaka Pelajar Offset.

Hasibuan, M. 2003. Manajemen Sumber Daya Manusia, Jakarta : PT. Bumi Aksara

Hasil-hasil Kongres HMI XXVII. Depok. 2013. tentang Pedoman Perkaderan. Depok: tanpa penerbit hlm. 301-392. 
Hidayat, K dan Putut, W. 2008. Reinventing Indonesia, menemukan kembali masa depan bangsa. Jakarta Mizan.

HMI Cabang Medan. Periode 2014-2015. Buku Panduan MOP, Medan: tanpa penerbit.

Hornby, A.S. 2006. Oxford Advanced Learner's Dictionary. Oxford University Press,

Kaelan. 2005. Metode Penelitian Kualitatif Bidang filsafat. Yogyakarta: Paradigma.

Kanter, R. M. 1977, Restoring People to The Hearth of the Organization of the Future, in the Organization Future. San Francisco: Jossey Bass Publisher.

Karim, M.R. 1995. Dinamika Islam di Indonesia: Suatu tinjauan Sosial dan Politik, Yogyakarta: Hanindita.

Kartasasmita, G. 1996. Pembangunan Untuk Rakyat Memadukan Pertumbuhan Dan Pemeraan. Jakarta : PT. Pustaka Cidesindo.

Kartodirjo. S. 1993. Pendekatan Ilmu Sosial dalam Metodologi Sejarah, Jakarta: PT. Gramedia Pusaka Utama.

Korver, A.P.E. 1985. Sarekat Islam Gerakan ratu Adil? Jakarta: Grafiti Press. Kuntowijoyo. 1993. Metodologi Sejarah, Yogyakarta: Universitas Gajah Mada. 1991. Paradigma Islam, Interpretasi Untuk Aksi, Bandung: Mizan.

Naim, M. 1979. Merantau, Pola Migrasi Suku Minangkabau, Yogyakarta: Gajah Mada University Press.

Nasution, H. 1995. Islam Rasional, Bandung: Mizan.

Nawawi, Hadari. (1997). Manajemen Sumber Daya Manusia Untuk Bisnisyang Kompetitif. Gajah Mada University-Press, Yogyakarta

Ndraha, T. 1997. Budaya Organisasi. Jakarta: Rineka Cipta.

Noer, D. 1983. Islam, Pancasila dan Azaz, Tunggal, Jakarta: Perkhidmatan.

Notoatmodjo, S. 2003. Pendidikan Dan Perilaku Kesehatan. RinekaCipta. Jakarta 
Notoatmojo, S, 2009. Pengembangan sumber Daya Manusia. Jakarta: Rineka Cipta.

Mathis, R dan Jackson, W.2006. Human Resources Development (Track MBA Series/Terjemahan). Jakarta; Prestasi Pustaka

Matindas, R. 1997. Manajemen SDM Lewat Konsep Aku. Jakarta : PT. Pustaka Utama Grafiti.

Mullins, J. W., Orville C. Walker Jr., Jean C. L, and Harper W. B. 2005. Marketing Management : A Strategic Decision Making Approach, Fift Edition. New York : The Mc Graw - Hill companies.

Pandapotan, S. 2006. Proses Adaptasi Etnis Jawa Asal Solo di Kota Medan, Medan: Program Pasca Sarjana Universitas Negeri Medan.

Partanto, P.A., Muhammad, D.A. 1994. Kamus Ilmiah Populer, Surabaya: Arkola, hal. 293-294

PB HMI. 2006. Hasi-hasil Kongres XXV 2006, Makasar: tanpa penerbit.

Pelly, U. 1989. Hubungan Antar Kelompok Etnis, Beberapa Kerangka Teoritis Dalam Kasus Kota Medan dalam Interaksi Antar Suku Bangsa Yang Majemuk, Jakarta: Deapartemen Pendidikan dan Kebudayaan.

Prasetyo B, Dan Lina M.J. 2005. Metode Penelitian Kuantitatif: Teori dan Aplikasi. Jakarta: Penerbit PT.Raja Grafindo Persada.

Prima, B. 2011. Pemuda dan Pergerakannya, Online: 16 Juli 2011, tersedia: http://www.kompasiana.com/yhoeldy/nilai-nilaisejarahpergerakanpemudaindonesia_550f39a4a333117732ba7fd

Rahman, Fazlur. 1980. Tema-tema Pokok Al-Qur'an, ter. Anas Mahyuddin, Bandung: Pustaka.

Rahardjo, D.M. 1993. Intelektual Inteligensia dan Perilaku Politik Bangsa, Risalah Cendikiawan Mulim, Bandung: Mizan. 
Rais, Amien, M. 1994. Cakrawala Islam, Antara Cita dan Fakat, Bandung: Mizan.

Redatin, P. 2006. Kaderisasi organisasi dalam Perubahan. Jurnal Wawasan, Juni 2006, Volume 12, Nomor 1

RI. 2009. Undang-undang Republik Indonesia Nomor 40 Tahun 2009 tentangKepemudaan. Jakarta: Sinar Grafika

Rivai, V.2006. Kepemimpinan dan Perilaku Organisasi, Jakarta : PT Raja Grafindo persada cet ke- 3 hal 85, 86, 90,91

Robbin, S.P. 1990, Organization Theory: Stucture, Design and.

Schuler, R.S., Susan E. 1997. Manajemen Sumber Daya Manusia Menghadapi Abad ke-21 Edisi Enam jilid 1, Jakarta: Erlangga.

Sedarmayanti. 2001. Sumber Daya Manusia Dan Produktivitas Kerja. Jakarta: Mandar Maju.

Sembiring, K.P. 1997, Corak dan Pola Hubungan Sosial Antara Golongan dan Kelompok Etnik di Daerah Perkotaan, Jakarta: Depaetemen Pendidikan dan Kebudayaan.

Singarimbun, M, dan Sofian, E. 2011. Metode Penelitian Survei, Jakarta: Pustaka LP3ES.

Sitopul, A. 1976. Sejarah Perjuangan Himpunan Mahasiswa Islam Tahun 19471975, Surabaya: Bina Ilmu

\section{--------------------. 1984. HMI Dalam Pandangan Seorag Pendeta. Jakarta: PT Gunung Agung. 1995. Historiografi Himpunan Mahasiswa Islam Tahun 1947- 1993, Jakarta: Intermasa. 1997. 50 Tahun HMI Mengayuh di Antara Cita dan Kritik.} Yogyakarta: Aditya Media. 
1997. HMI dan Relevansinya Dengan Sejarah Perjuangan

Bangsa. Jakarta: Aditya Media.

1997. Citra HMI. Yogyakarta: Aditya Media.

2002. Menyatu Dengan Ummat Menyatu Dengan Bangsa:

Pemikiran Keislaman Keindonesiaan HMI 1947-1997. Jakarta: Logos. 44 Indikator Kemunduran HMI. hlm. 38.

Smith, SE dan Read, DJ. 1997. Mycorrhizal Symbiosis. Second edition.Academic. London: Press. Harcourt Brace \& Company Publisher.

Soekanto, S. 1990. Sosiologi Suatu Penghatar, Jakarta: PT Raja Grafindo Persada, hal, 268.

Subadi. 2009. Sekilas Tentang Terjadinya Sumpah Pemuda, Online, 30 Oktober 2009, Selenkapnya: http://www.kompasiana.com/yhoeldy/nilainilai- sejarah-pergerakan-pemuda-indonesia_550f39a4a333117732bafd7

Subandi. 2012. Ekonomi Pembangunan. Jakarta: Alfabeta.

Subirin, A. 2007. Budaya Organisasi, Yogyakarta: UPP STIM YKPN.

Sugiyono. 2007. Metode Penelitian Pendidikan Pendekatan Kuantitatif, Kualitatif Dan $R \& D$. Bandung: ALFABETA

Sugiyono. 2013. Metode Penelitian Pendidikan Pendekatan Kuantitatif, Kualitatif Dan $R \& D$. Bandung: ALFABETA

Suharsaputra, U. 2012. Metode Penelitian Kuantitatif, Kualitatif, Dan Tindakan. Bandung: Refika Aditama.

Sudjana. 2005. Metode Statistika Edisi ke-6. Bandung : Tarsito

Sumarsono, S. 2003. Ekonomi Manajemen Sumber Daya Manusia Dan Ketenaga Kerjaan. Jogyakarta : Graha Ilmu.

Tarigan, Azhari Akmal. 2007. Islam mazhab HMI : tafsir tema besar nilai dasar perjuangan (NDP). Cipayung, Ciputat: Kultura. 
Udaya, J. 1994. Teori Organisasi: Struktur, Desain \& Aplikasi, Jakarta: Arcan.

Yosita, L. 2006. Kepemimpinan Pemuda Indonesia, Apakah Akar Permasalahannya? Pemenang Hiburan 3 dalam Lomba Menulis Esai Kepemudaan, memperingati Hari Sumpah Pemuda ke-78, 28 Oktober 2006, yang diadakan oleh Kemenpora bekerja sama dengan Forum Lingkar Pena (FLD).

Wexley dan Yukl. 1976. Menadi Guru Profesional. Bandung: Remaja Rosdakarya 